\title{
THE IMPLEMENTATION OF COMMUNICATIVE LANGUAGE TEACHING (CLT) IN AN EFL CONTEXT: A CASE STUDY OF LEARNERS' ATTITUDES AND PERCEPTIONS
}

\author{
Ekrem Eroz, Azamat A. Akbarov \\ International Burch University, Bosnia and Herzegovina
}

\begin{abstract}
This research study investigates the place of communicative language teaching in one of the capital Balkan cities in Sarajevo, in Bosnia by exploring attitudes and perceptions of Bosnian EFL students. A questionnaire survey was conducted to collect data from the target EFL learner groups. The findings of the survey revealed that Bosnian learners have positive views and attitudes toward communicative language teaching. According to Hymes (1972), the goal of language teaching is to improve the communicative competence of learners. That is why, educators should focus on the communication skills of learners rather than their grammar-based knowledge and being able to communicate effectively in the target language is the most important of all skills. However, some external factors, like exam system, high number of students in the classes, can be barriers to implement CLT effectively in different EFL contexts and they force teachers to use traditional methods in language teaching but this presumption is lower or almost unlikely in private education institutions thanks to the amenities. Supporting the view above, the results of survey also reported that EFL learners have favourable beliefs for the use of CLT in their classrooms and they believe that as a foreign language English learning is very important in their country and for their future careers.
\end{abstract}

Key words: EFL (English as a Foreign Language), learner beliefs, communicative competence, CLT (communicative language teaching), English language teaching.

\section{Introduction}

The language teaching methods are substantially needful for the purpose of learning and teaching in every language and CLT approach contrasts sharply with established traditions that emphasize learner knowledge of formal features. Hereby, communicative language teaching is an important theoretical model in the world of ELT and it is accepted and used by a number of educators as one of the most effective teaching approaches. Richard and Rodgers (1986) state the emergence of CLT occurred at the time when language teaching was looking for a change.

CLT was developed in the late 1970s and widely used and applied to ESL contexts. Britain, North America, Australia, New Zealand and other surrounding islands applied CLT in their ESL settings. In these contexts, English language learning does not take place in large class size which impedes pair and group works and on the contrary to traditional approaches, it usually shows up in small classes by welcoming and encouraging collaborative 
independent learning through pair and group works. Chang (2011) mentions that the main purpose of CLT is to develop learners' abilities to communicate in a second language context and it represents a change of focus in language teaching from linguistic structure to learners' need for developing communication skills.

To compensate for the limitations of the traditional language teaching methods, communicative language teaching (CLT) has been introduced in EFL settings to improve students' abilities to use English in real contexts (Littlewood, 2007). However, in some EFL settings, the theories and practices of CLT have come up against various challenges (Ellis, 1996; Li, 1998; Takanashi, 2004; Yu, 2001). In recent years, educators and especially language teachers in many countries, including Bosnia and Herzegovina, have been encouraged to adopt a method or can be said an approach known as CLT. It advocates the development of communicative competence as a primary goal by means of the extensive use of the foreign language as a means of communication during classroom sessions. Since the concept of CLT is a western idea, seemingly it might be inappropriate to other contexts. That is why it is significant to do a research on the attitudes and perceptions of high school learners towards CLT. Learners' views of learning cannot be ignored when there is a mismatch between the teachers' and learners' beliefs (Schulz, 1996).

Savignon (1997) emphasizes the importance of learner attitudes by explaining 'if all the variables in second language acquisition could be identified and many intricate patterns of interaction between learner and learning context, success in learning to use a second language most likely would be seen to depend on the attitudes (perceptions) of the learner. Most studies just investigate learners' attitudes and beliefs about language learning in general, only few of them focus on learner attitudes and beliefs about instructional practices in particular. That is why, Nunan (1993) discusses 'teachers should find out what their students think and feel about what and how they want to learn'. Additionally, the extent to which communicative components in instructional practices are seen by students as essential for language learning should be considered in making pedagogical decisions.

Competent English users are in great demand in Bosnia and Herzegovina, in Europe, where English serves as bridge between people from different cultures and countries as well as a communication tool for the exchange of knowledge and information in the areas of culture, technology and business etc. After the war, Ministry of Education gradually has made some changes in English education policy to raise and increase the learners' communicative competence in English and it has a pivotal role in language education in Bosnia and Herzegovina so far.

The present research investigated high school learners' beliefs, attitudes and perceptions of the classroom practices they had experienced in their EFL classes.

The specific research questions addressed in this research are:

1. What are Sarajevo College students' beliefs about English language learning generally?

2. What are Sarajevo College students' perceptions of the classroom practices they have experienced in their English lessons?

3. What are Sarajevo College students' attitudes toward such classroom practices? 


\section{Methodology of Research}

\section{Participants}

Sixty-seven high school students participated in this research and answered the questionnaire which aimed at reflecting their attitudes, perceptions and classroom practices towards CLT in the case of BH. The participants were 12 grade students studying in Sarajevo College in the capital of Bosnia and Herzegovina. In selecting the participants, a convenience sampling was employed as all contributors were from Sarajevo College.

\section{Instrument and procedures}

A qualitative method was adopted to gather data from high school students. Actually, Savignon and Wang's (2003) questionnaire was applied to Bosnian context. The questionnaire, which has a total of 48 items, is divided into three parts (Appendix 1). In the first two parts, each involves eleven statements related to perceptions of classroom learning experiences. The first 5 statements relate to form focused (grammar-based) classroom practices but the pair 5 statements relate to meaning-based (communication-based) classroom practices. The last statements of the first part relate to students' attitudes toward error correction. The last adopted part of the questionnaire involves 28 statements that relate to students' beliefs about English learning.

Statements 1 to 11 are similar to the eleven statements in first parts of both questionnaires. Besides, statements 12 to 16 refer to beliefs about grammar-focused instruction, statements 17 to 19 concern students' beliefs about meaning-based instruction, statements 22 and 23 are related to pronunciation, Finally, the last three statements are concerned with learner perceptions of the interrelationship between language learning ability and intelligence. All the responses were scored on a Likert scale from 1 to 7 ( 1 coded as strongly disagree and 7 coded as strongly agree). The instructions and statements of learner questionnaire were translated into Bosnian and vetted by a Bosnian instructor of English for clarity and accuracy. To make certain of the comprehensibility of the questionnaire, it was administered to a test group of college students and then finalized according to their feedback. The data was interpreted as $(1.00-2.19)=$ strongly disagree, $(2.20-3.39)=$ disagree, $(3.40-4.59)=$ neutral, $(4.60-5.79)=$ agree,$(5.80-7.00)=$ strongly agree .

\section{Results of Research}

Table 1 below presents Sarajevo College students' beliefs about English learning. According to gathered data, students have strong beliefs about practices that engaged students through communication $(\mathrm{M}=5.88$ / Strongly Agree). On the other hand, there is an agreement about error correction. Sarajevo College students agree that teachers should correct errors in class $(\mathrm{M}=4.85$ / Agree). As for pronunciation, the data reveals an agreement to consider pronunciation as a measure for being a good learner and good English speaker (Mean = 5.29 / Agree). Moreover, concerning students' attitudes toward English, the data presents strong beliefs that English learning is important for the people living in Bosnia and Herzegovina and English is needed to get a good job, and English education should begin in elementary school $(\mathrm{M}=5.93$ / Strongly Agree). 
Table 1. Beliefs about learning English.

\begin{tabular}{|l|l|l|}
\hline \multicolumn{1}{|c|}{ Item } & \multicolumn{1}{|c|}{ Mean } & \multicolumn{1}{c|}{ Standard Deviation } \\
\hline Grammar-based: $1-5$ and $12-16$ & $3.62^{\mathrm{N}}$ & 0.45 \\
\hline $\begin{array}{l}\text { Communication-based: } 6-10 \\
\text { and 17-19 }\end{array}$ & $5.88^{\mathrm{SA}}$ & 0.29 \\
\hline Error correction: 11, 20, 21 & $4.85^{\mathrm{A}}$ & 1.43 \\
\hline Pronunciation 22, 23 & $5.29 \mathrm{~A}$ & 0.61 \\
\hline $\begin{array}{l}\text { Attitude toward English: } 24, \\
25,28\end{array}$ & $5.93^{\mathrm{SA}}$ & 0.22 \\
\hline $\mathrm{n}=67$ SD = strongly disagree & $\mathrm{N}=$ neutral A= agree $\mathrm{SA}=$ strongly agree \\
\hline
\end{tabular}

Table 2 below presents Sarajevo College students' perceptions of the English language classroom instructions they had experienced in their English classes. The mean (2. 69 / Disagree) of items one to five indicated that these experiences had not been formbased (grammar-based), i.e. teachers use Bosnian most of the times, and students rarely speak English. Communication was most commonly reported in the classroom activities. Although students reported that their English teachers corrected their errors in class, little correction placed $(\mathrm{M}=4.65$ / Agree).

Table 2. Perceptions of Classroom Practices.

\begin{tabular}{|c|c|c|}
\hline Items & Mean & Standard Deviation \\
\hline $\begin{array}{l}\text { 1. Grammar-focused English teaching Učenje } \\
\text { Engleskog jezika je učenje njegove gramatike. }\end{array}$ & $3.31 \mathrm{D}$ & 1.21 \\
\hline $\begin{array}{l}\text { 2. Sentence drilling and sentence repetition Učenje } \\
\text { Engleskog jezika kroz treniranje rečenica je efikasno. }\end{array}$ & $2.83 \mathrm{D}$ & 0.88 \\
\hline $\begin{array}{l}\text { 3. Bosnian used most of the time } \\
\text { Vjerujem da bi Bosanski jezik trebao biti često } \\
\text { korišten na časovima engleski jezika zbog } \\
\text { razumjevanja lekcija. }\end{array}$ & $1.94 \mathrm{SD}$ & 0.54 \\
\hline $\begin{array}{l}\text { 4. Most time spent on grammar rules } \\
\text { explanation } \\
\text { Vjerujem da onaj ko više zna u upotrebi } \\
\text { Engleskog jezika. }\end{array}$ & $3.05 \mathrm{D}$ & 0.91 \\
\hline $\begin{array}{l}\text { 5. Seldom needed to open my mouth Povremeno } \\
\text { javljanje na času Engleskog jezika nije neopdodno za } \\
\text { učenje englesko jezika. }\end{array}$ & $2.34 \mathrm{D}$ & 1.02 \\
\hline Mean of Items 1 to 5 & $2.68 \mathrm{D}$ & 0.92 \\
\hline
\end{tabular}




\begin{tabular}{|c|c|c|}
\hline $\begin{array}{l}\text { Communication-based } \\
\text { 6. Communication-based teaching practices Časovi } \\
\text { na kojima se uči Engleski jezik trebali bi biti } \\
\text { komunikacijski fokusirani. }\end{array}$ & $5.01 \mathrm{~A}$ & 1.23 \\
\hline $\begin{array}{l}\text { 7. Many activities involving communication Važno } \\
\text { je vježbati Engleski jezik u stvarnom životu ili u } \\
\text { životnim situacijama. }\end{array}$ & $5.85 \mathrm{SA}$ & 0.54 \\
\hline $\begin{array}{l}\text { 8.Communication-focused with grammar explained } \\
\text { when } \\
\text { Necessary Jezici se uče uglavnom kroz komunikaciju } \\
\text {, sa objašnjenjem gramatike kada je potrebno. }\end{array}$ & $4.48 \mathrm{~A}$ & 0.26 \\
\hline $\begin{array}{l}\text { 9. Trial-and-error attempts allowed } \\
\text { Vjerujem da pokušaji griješenja i } \\
\text { ispravljanja u komunikaciji pomažu mi da naučim } \\
\text { Engleski jezik. }\end{array}$ & $5.56 \mathrm{~A}$ & 0.38 \\
\hline $\begin{array}{l}\text { 10. Atmosphere created for the use of English } \\
\text { Profesor bi trebao stvoriti atmosferu u razredu } \\
\text { da podstakne komunikaciju razreda ili gtupe učenika }\end{array}$ & $5.45 \mathrm{~A}$ & 0.77 \\
\hline Mean of Items 6 to 10 & $5.27 \mathrm{~A}$ & 0.63 \\
\hline $\begin{array}{l}\text { Error correction } \\
\text { 11. Teachers corrected my errors in class Važno je } \\
\text { da profesor ispravlja greške učenika. }\end{array}$ & $4.71 \mathrm{~A}$ & 1.52 \\
\hline
\end{tabular}

$\mathrm{n}=67 \mathrm{SD}=$ strongly Disagree $\quad \mathrm{N}=$ neutral $\quad \mathrm{A}=$ agree $\quad \mathrm{SA}=$ strongly agree

Table 3 below presents Sarajevo College students' attitudes towards the English language classroom practices students had experienced in English classrooms. The mean (2.39) of items 1 to 5 shows that Sarajevo College students' dislike grammar-based (formbased) instruction, English teachers use Bosnian most of the times and students seldom speak English in class, which they disliked. On the contrary, communication-based (meaningbased) practices $(\mathrm{M}=5.99 \mathrm{SA})$ were highly regarded as well as EFL teachers' correcting their errors in class $\left(\right.$ mean $\left.=5.73^{\mathrm{SA}}\right)$. 
Table 3. Attitude towards Perceived Classroom Practices.

\begin{tabular}{|c|c|c|}
\hline Items & Mean & Standard Deviation \\
\hline $\begin{array}{l}\text { Form-based } \\
\text { 1. Grammar-focused English teaching Volim učenje } \\
\text { engleskog jezika fokusirano na gramatiku u mojoj školi. }\end{array}$ & $2.88 \mathrm{D}$ & 0.84 \\
\hline $\begin{array}{l}\text { 2. Sentence drilling and sentence repetition Volim } \\
\text { vježbanje i ponavljanje rečenica poslije profesora na } \\
\text { času engleskog jezik. }\end{array}$ & $3.01 \mathrm{D}$ & 0.17 \\
\hline $\begin{array}{l}\text { 3. English used most of the time } \\
\text { Volio bih da profesori engleskog jezika } \\
\text { najviše koriste bosanski jezik na časovima. }\end{array}$ & $1.89 \mathrm{SD}$ & 0.26 \\
\hline $\begin{array}{l}\text { 4. Most time spent on grammar rules explanation } \\
\text { Volio bih da više na času provodimo vježbajući I } \\
\text { objašnjavajući pravila gramatike. }\end{array}$ & I.51 D & 0.27 \\
\hline $\begin{array}{l}\text { 5. Seldom needed to open my mouth } \\
\text { Volim čas engleskog jezika u kojem nemam } \\
\text { potrebu govoriti. }\end{array}$ & $1.73 \mathrm{SD}$ & 0.15 \\
\hline Mean of Items 1 to 5 & $2.40 \mathrm{D}$ & 0.34 \\
\hline $\begin{array}{l}\text { Communication-based } \\
\text { 6. Communication-based teaching practices Volim učiti } \\
\text { engleski jezik baziran na komunikaciji. }\end{array}$ & ti $6.02 \mathrm{SA}$ & 0.41 \\
\hline $\begin{array}{l}\text { 7. Many activities involving communication } \\
\text { Volim aktivnosti u kojima mogu } \\
\text { komunicirati sa } \\
\text { svojim.vršnjacima. }\end{array}$ & $6.06 \mathrm{SA}$ & 0.35 \\
\hline $\begin{array}{l}\text { 8. Communication-focused with grammar explained } \\
\text { when necessary } \\
\text { Volim da moji časovi engleskog jezika budu fokusirani } \\
\text { na komunikaciji sa objasnjenjem gramatike kada je } \\
\text { potrebno. }\end{array}$ & di & 0.23 \\
\hline $\begin{array}{l}\text { 9. Trial-and-error attempts allowed } \\
\text { Volim profesore engleskog jezika koji nam dopuštaju da } \\
\text { pokušamo i pogriješimo u komunikaciji na engleskom } \\
\text { jeziku. }\end{array}$ & $5.77 \mathrm{~A}$ & 0.40 \\
\hline $\begin{array}{l}\text { 10. Atmosphere created for the use of English } \\
\text { Volim profesore engleskog jezika koji stvaraju atmosferu } \\
\text { koja nas ohrabruje na učenje engleskog jezika. }\end{array}$ & $6.27 \mathrm{SA}$ & 0.30 \\
\hline Mean of Items 6 to 10 & $6.01 \mathrm{SA}$ & 0.34 \\
\hline \begin{tabular}{|l} 
Error correction \\
11. Teachers corrected my errors in class Volim kada me \\
profesor ispravlja ako napravim $\quad$ grešku \\
tokom $\quad$ govora na engleskom jeziku.
\end{tabular} & $5.84 \mathrm{SA}$ & 1.37 \\
\hline
\end{tabular}




\section{Discussion}

In this section, the three research questions are sequentially answered as follows:

1) What are Sarajevo College students' beliefs about English language learning?

The findings for this research question report Sarajevo College students' strong beliefs about practices that engaged them in meaningful language production (communication based) as contrary to grammar-based (form-based) instructions. The results of the study revealed that students' beliefs about communication-based practices might have been affected by their classroom practices. It can be easily interpreted that Sarajevo College students were provided by their English teachers with a range of communicative tasks and activities which engaged them in meaningful language production.

With regard to error correction, there was an agreement that students refused to be corrected by their teachers in classroom and it can be inferred from the findings that EFL teachers shouldn't correct students' errors in the classroom. Students expressed an agreement with such statements as: 'I believe it is important to avoid making errors in the process of learning English', and 'Teachers should correct students' pronunciation or grammatical errors in class'. Although there was an agreement with these three statements, the mean of 4.85 which is just between neutral and agree, reports that the majority of students showed favorable attitudes towards making mistakes and error correction. It is clear from the table that many of the students were neutral and did not agree with the 3 statements towards error corrections.

Concerning pronunciation, Sarajevo College students regard pronunciation as a measure for being a good student or a good English speaker. Students showed their favorable attitudes towards such statements as 'A good language learner usually pronounces beautifully' and 'A person's good pronunciation usually indicates good English'. Finally, the findings revealed a strong belief that learning English is important for Bosnian people, English is useful for getting a job, and that English education should begin earlier. It is clear that students are aware of the importance of English in their country in this global world.

2) What are Sarajevo College students' perceptions of the classroom practices they have experienced?

According to data gathered for the second research question, it is clear that English language teaching was perceived to be communication-based (meaning-based). Furthermore, almost all students stated having experienced a communicative approach in their EFL classrooms. These findings are consistent with the students' strong beliefs about practices that engaged them in communication-based instructions. It is obvious that their strong perceptions derive from their steady and strong beliefs. Additionally, students' high perceptions of communication-based instruction must have been affected by communicative classroom atmosphere they have experienced. Games, role-plays, presentations, pair and group work activities are important to negotiate meaning. Grammar structures were thought to be introduced when the need arose. 
3) What are Sarajevo College students' attitudes towards classroom practices?

The results for the third research question revealed that teaching practices were communication-based, when many activities involved communication, grammar was explained when necessary during communication-focused (meaning-based) activities, and when the classroom atmosphere allowed for the use of English. Sarajevo College students' attitudes were consistent with their perceptions and beliefs. Even if there was little error correction in the EFL classroom, Bosnian students preferred to have their errors in speaking, pronunciation and grammar corrected. The results are consistent with the data found in the group of Taiwan English language teacher educators reported in Wang (2002).

\section{Conclusions}

The findings of this study reveal that Sarajevo college students hold beliefs which are consistent with different methodological orientations to learning English language and had strong beliefs in the influence on their high perceptions of the meaning-based practices in their classroom. These findings reveal that teachers should take advantage of these strong realistic beliefs, perceptions and favorable attitudes to create learning surroundings useful for developing learners' communicative competence. All in all, teaching for communicative competence appears to be the appropriate guiding principle of English pedagogy in such settings as Bosnia and Herzegovina, where learners and the society as a whole expect and value communicative skills. It can be concluded that students may have experienced communication-based instruction in their school and that oral communication is the major goal of English education in Sarajevo College. Finally, students' highly regard classroom practices that encourage the EFL learners to use the target language communicatively.

\section{References}

Chang, M. (2011). EFL teachers' attitudes toward communicative language teaching in Taiwanese college. Asian EFL Journal, 53, 17-34.

Littlewood, W. (2007). Communicative and task-based language teaching in East Asian classrooms. Language Teaching, 40, 243-249.

Takanashi, Y. (2004). TEFL and communication styles in Japanese culture. Language, Culture and Curriculum, 17 (1), 1-14.

Ellis, G. (1996). How culturally appropriate is the communicative approach? ELT Journal, 50 (3), 213-218.

Li, D. (1998). It's always more difficult than you plan and imagine: Teachers' perceived difficulties in introducing the communicative approach in South Korea. TESOL Quarterly, 32 (4), 677-703.

Yu, L. (2001). Communicative language teaching in China: Progress and resistance. TESOL Quarterly, 35 (1), 194-179.

Richards, J. C., \& Rodgers, T. S. (1986). Approaches and methods in language teaching. Cambridge: Cambridge University Press.

Schulz, R. A. (1996). Focus on form in the foreign language classroom: Students' a teachers' views on error correction and the role of grammar. Foreign Language Annals, 29 (3), 333-364. 
Savignon, S. J. (1997). Communicative competence: Theory and classroom practice. 2nd edition. New York: McGraw- Hill.

Nunan, D. (1993). From learning-centeredness to learner-centeredness. Applied Language Learning, 4, 1-18.

Wang, Ch. (2002). Innovative teaching in EFL contexts: The case of Taiwan. New Haven: Yale University Press, p. 131-153.

Received 15 November 2015; accepted 20 December 2015

\begin{tabular}{|l|}
\hline Ekrem Eroz \\
PhD.c, International Burch University, Bosnia and Herzegovina. \\
E-mail: ekremeroz@gmail.com \\
Website: http://www.ibu.edu.ba/ \\
\hline Azamat A. Akbarov \\
PhD., International Burch University, Bosnia and Herzegovina. \\
E-mail: azamatakbar@yahoo.com
\end{tabular}

